\title{
Cassava diet and cyanide metabolism in Wistar rats
}

\author{
By B. O. OSUNTOKUN \\ Department of Psychiatry and Neurology, University of Ibadan, \\ Ibadan, Nigeria
}

(Received 30 December 1969-Accepted I8 March 1970)

\begin{abstract}
I. In the aetiopathogenesis, in Nigerians, of a degenerative neuropathy known as tropical ataxic neuropathy, chronic cyanide intoxication is believed to be the most important factor. The source of the cyanide is cassava (Manihot) and in Nigerian patients, plasma concentration of thiocyanate, a major detoxication product of cyanide, is high.

2. Since there is considerable doubt as to whether cyanide is readily released from cassava diet after ingestion, rats were fed on 80 and $100 \%$ purupuru (a cassava derivative) diets for periods varying between 6 and 18 months and their plasma thiocyanate levels were studied. Control rats were fed on a normal diet for the same periods.

3. Rats fed on the $100 \%$ purupuru diet were malnourished. Rats fed on the $80 \%$ purupuru diet appeared normal, although their mean weight was less than the mean weight of rats fed on the normal diet.

4. Plasma thiocyanate was significantly higher in rats fed the purupuru diets than in the rats fed on the normal rat diet.

5. The concentration of thiosulphate sulphurtransferase, the enzyme that catalyses the conversion of cyanide into thiocyanate was the same in rats fed on the purupuru diets as in the control rats.

6. The results suggest that raised plasma thiocyanate levels found in Nigerian patients with ataxic neuropathy, as in rats fed cassava diet, is the result of detoxication of cyanide, as the concentration of thiocyanate in cassava and most food products eaten by Nigerians is low.
\end{abstract}

A degenerative disease known as ataxic neuropathy is prevalent in certain areas of southern Nigeria (Money, r959; Osuntokun, 1968, 1969; Osuntokun, Monekosso \& Wilson, 1969). There is a wealth of evidence that the most important factor in the aetiopathogenesis is chronic cyanide intoxication of dietary origin (Monekosso \& Wilson, I966; Osuntokun, I968, 1969). The source of the cyanide is cassava (commonly Manihot utilissima and $M$. palmata), which contains cyanogenetic glycosides (Clark, 1935, 1936; Oke, 1966). In Nigerian patients with this disease, concentrations of plasma thiocyanate and cyanide and urinary exretion of thiocyanate are raised. The levels fall when the patients are fed on cassava-free diets but rise again when the patients revert to a cassava-containing diet, which is usually associated with clinical deterioration (Monekosso \& Wilson, I966; Osuntokun, I968, 1969). The concentration of thiocyanate in most cassava derivatives commonly consumed by Nigerians is

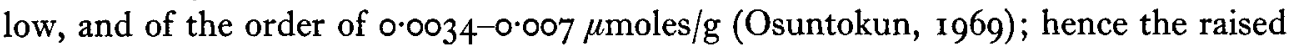
plasma thiocyanate may be attributable to detoxication of dietary cyanide. Various preparations of cassava commonly consumed in Nigeria are known to contain cyanogenetic glycosides and to yield hydrocyanic acid on hydrolysis. The yield of cyanide varies between 0.4 and 2.5 $\mu$ moles/g (Osuntokun, 1969). It has, however, been well established that the different cyanogenetic glycosides in food consumed by man vary in their rate of hydrolysis and may not all yield hydrocyanic acid in vivo or in vitro (Viehoever, I940; Montgomery, 1964). Montgomery (1965), for example, stated that 
the toxicity of the intact glycoside has never been demonstrated. This implied that the acute poisoning reported in patients who ate cassava (Clusius, 1605 ; Carmody, I900; Nicholls, 195I) was due to preformed hydrocyanic acid produced by hydrolysis of cyanogenetic glycosides in vitro before consumption rather than from hydrolysis of ingested glycosides.

Clark (I935) fed rats on cassava (gari) and water, and reported histological lesions such as fatty liver and tubular degeneration of renal tubules, accompanied by albuminuria. He did not report on the plasma thiocyanate levels. I have therefore fed Wistar rats with a derivative of cassava, purupuru, to determine its effects on plasma thiocyanate levels and on the activity, in various tissues of rats, of thiosulphate:cyanide sulphurtransferase (thiosulphate sulphurtransferase). Thiosulphate sulphurtransferase, an enzyme present in high concentration in the liver, kidney and most other tissues, catalyses the conversion of cyanide into thiocyanate (Lang, 1933; Sorbo, 1953). Purupuru is prepared from the tuber or root of cassava (usually M. utilissima) by soaking it in stagnant water and allowed to ferment for 2 or $3 \mathrm{~d}$. The root is then mashed by hand into balls, dried by sun and powdered. It is boiled into a paste, and eaten with vegetable soup by Nigerians. The paste from purupuru contains 2-6 mg hydrocyanic acid/100 g (Oke, I966; Osuntokun, I968, 1969); the protein and carbohydrate contents are $0.6 \mathrm{~g} / \mathrm{100} \mathrm{g}$ and $78 \mathrm{~g} / \mathrm{100} \mathrm{g}$ respectively (Oke, 1966; Osuntokun, 1968, 1969). Some Nigerians may consume 2-3 kg purupuru daily. All cassava derivatives are deficient in sulphur-containing amino acids (Jones, 1959).

\section{EXPERIMENTAL}

Sixteen albino Wistar rats weighing between $\mathrm{I} 65$ and $200 \mathrm{~g}$ were fed for $6-\mathrm{I} 8 \mathrm{months}$ on a diet of 80 or $100 \%$ purupuru. Sixteen normal rats of the same age group and weight were given a normal standard diet-Oxoid modified diet $4^{\mathrm{I}} \mathrm{B}$ or calf nutsfor the same period. At intervals, the rats were bled by laparotomy under diethyl ether anaesthesia and venepuncture of the inferior vena cava. The plasma was analysed for thiocyanate by the method of Aldridge (1944). After death, sections of liver, kidneys, duodenum, heart, gastrocnemius muscles and brain were taken and immediately deep-frozen at $-20^{\circ}$ in 3 drops of $0.0125 \mathrm{M}$-sodium thiosulphate. Thiosulphate sulphurtransferase was later determined in homogenates of tissues and in an acetone extract of the brain by the method of Saunders \& Himwich (1950) as modified by Wilson (1965). Determinations were done within 2 weeks of collection of the specimens.

\section{RESULTS}

The rats on the $80 \%$ purupuru diet appeared normal in every respect except for slight loss of weight; after I8 months on this diet, the mean gain in weight was $75 \mathrm{~g}$, while the mean gain in weight in rats fed on normal diet for the same period was I $5 \mathrm{~g}$. The rats on $100 \%$ purupuru appeared malnourished, lost most of their fur and showed a mean gain in weight of only $5 \mathrm{~g}$.

Table $\mathrm{x}$ shows the plasma concentration of thiocyanate in rats fed on the purupuru diets and in rats on the normal diet. The difference was statistically significant $(P<0.001 ; t$ test). It would appear that the plasma thiocyanate level in rats fed on 
purupuru for 6 months is lower than that in rats fed on purupuru for I year or for I 8 months $(P<0.01)$.

Table 2 shows the activity of thiosulphate sulphurtransferase in various tissues in rats on purupuru and in rats on a normal diet. None of the differences between the groups was significant.

Table 1. Mean values with their standard errors for plasma thiocyanate concentration for rats fed on a normal diet and on purupuru (a cassava derivative; see p. 798)

\begin{tabular}{|c|c|c|c|c|}
\hline $\begin{array}{l}\text { No. of } \\
\text { rats }\end{array}$ & $\begin{array}{l}\text { Diet } \\
(\%)\end{array}$ & $\begin{array}{l}\text { Time on diet } \\
\text { (months) }\end{array}$ & $\begin{array}{l}\text { Plasma thiocya } \\
(\mu \text { moles/100 }\end{array}$ & $\begin{array}{l}\text { anate } \\
\mathrm{ml})\end{array}$ \\
\hline $\begin{array}{r}4 \\
10 \\
2\end{array}$ & $\begin{array}{r}100 \\
80 \\
100\end{array}$ & $\begin{array}{c}6 \\
12-18 \\
18\end{array}$ & $\left.\begin{array}{r}6.9 \pm 0.15 \\
10.5 \pm 0.57 \\
10.2\end{array}\right\}$ & $\begin{array}{l}\text { Mean value with } \\
\text { its standard error } \\
9^{\cdot 6 \pm 0.5 * * *}\end{array}$ \\
\hline 16 & Normal & $6-18$ & $4.7 \pm 0.45$ & \\
\hline
\end{tabular}

*** Significantly different from value for rats on a normal diet at $P<0.001$ ( $t$ test).

Table 2. Mean values with their standard errors for thiosulphate sulphurtransferase expressed as umoles thiocyanate formed per min per $\mathrm{mg}$ protein in homogenate of various tissues and lipid-free extract of brain in sixteen rats fed on a normal diet and sixteen rats fed on a 80-100\% purupuru diet (see p. 798) for 6-18 months

\begin{tabular}{lcc}
\multicolumn{1}{c}{ Tissue } & Rats on normal diet & Rats on purupuru \\
Liver & $0.49 \pm 0.04$ & $0.36 \pm 0.045$ \\
Kidney & $0.27 \pm 0.025$ & $0.25 \pm 0.035$ \\
Heart & $0.050 \pm 0.004$ & $0.058 \pm 0.007$ \\
Muscle & $0.021 \pm 0.003$ & $0.027 \pm 0.006$ \\
Lipid-free extract of brain & $0.073 \pm 0.0025$ & $0.071 \pm 0.002$ \\
Duodenum & None & None
\end{tabular}

\section{DISCUSSION}

The results show that Wistar rats are unable to maintain normal growth on a diet consisting of $100 \%$ purupuru, although considerable growth occurred in rats fed on the $80 \%$ purupuru diet. However, even in those rats fed on the latter diet, growth was depressed compared with growth in rats on a stock laboratory diet. The $80 \%$ purupuru diet has some similarity to the dietary pattern of Nigerian patients with ataxic neuropathy (Osuntokun, I968, I969). These patients consume cassava meals three times a day, usually with vegetable soup and dried stock-fish, although occasionally they eat meat and other food items such as maize, beans, rice, plantain and yam.

In rats fed on the purupuru diets, plasma thiocyanate levels were raised compared with normal controls and the raised levels were not associated with reduced activity of thiosulphate sulphurtransferase in parenchymal organs, including the brain. This suggests that the concentration of thiosulphate sulphurtransferase in tissues is not the limiting factor in the detoxication of cyanide from cassava meals and that conversion into thiocyanate probably occurs normally. This too has similarities to the situation in the Nigerian patients with ataxic neuropathy in whom concentrations of plasma thiocyanate are raised also and in whom thiosulphate sulphurtransferase activity in the liver is normal (Osuntokun, 1969). 
The loss of fur in the rats on $100 \%$ purupuru may be due to either dietary lack of sulphur-containing amino acids in which cassava is deficient (Jones, 1959) or perhaps to a cyanide-conditioned deficiency of these amino acids. Cysteine and methionine constitute the major source of thiol groups and thiosulphate which can react with cyanide to form thiocyanate. Furthermore, cystine is known to combine in vivo with cyanide to form 2-aminothiazolidine-4-carboxylic acid (Wood \& Cooley, I956). In patients with the Nigerian ataxic neuropathy, sulphur-containing amino acids are either absent or occur in subnormal concentrations (Osuntokun, Durowoju, MacFarlane \& Wilson, 1968).

Two of the four rats (plasma thiocyanate was determined in only two) fed on $100 \%$ purupuru for $\mathrm{I} 8$ months developed clinical signs of ataxia. In these two rats, as well as in two other rats fed on $100 \%$ purupuru for 18 months and in four rats on $80 \%$ purupuru for 18 months, segmental demyelination was demonstrated in single nervefibre preparations from sciatic nerve (Vizoso \& Young, 1948) as reported in detail elsewhere (Osuntokun, 1969; Osuntokun \& Williams, 1970). Segmental and patchy demyelination has been described in the peripheral nerves of Nigerian patients who suffered from the ataxic neuropathy (Williams \& Osuntokun, 1969).

The results of this experimental study constitute further evidence in support of the aetiological role of a cassava diet in the pathogenesis of the Nigerian nutritional ataxic neuropathy.

This work was supported by research grants from the Wellcome Trust of Great Britain and the University of Ibadan, Ibadan, Nigeria.

\section{REFERENCES}

Aldridge, W. N. (1944). Analyst, Lond. 69, 262.

Carmody, L. (1900). Lancet ii, 736.

Clark, A. (1935). W. Afr. med. $\mathscr{7} .8,9$.

Clark, A. (1936). F. trop. Med. Hyg. 39, 269.

Clusius, C. (1605). Liber exoticorum. Leyden, 1605 (quoted in Bull. imp. Inst., Lond. (1906), 4, 334).

Jones, W. O. (1959). Manioc in Africa. Stanford, California: Stanford University Press.

Lang, K. (1933). Biochem. Z. 259, 243.

Monekosso, G. L. \& Wilson, J. (1966). Lancet i, ro62.

Money, G. L. (1959). W. Afr. med. F. 8, хз.

Montgomery, R. D. (1964). W. Indian med. $\mathcal{F} .13, \mathbf{1}$.

Montgomery, R. D. (1965). Am. F. clin. Nutr. 17, 103.

Nicholls, L. (195 I). Tropical Nutrition and Dietetics 3 rd ed. London: Baillière, Tindall and Cox.

Oke, O. L. (1966). Trop. Sci. 8, 23.

Osuntokun, B. O. (1968). Brain 9r, 215.

Osuntokun, B. O. (1969). Chronic cyanide intoxication and a degenerative neuropathy in Nigeria. $\mathrm{PhD}$ Thesis, University of Ibadan.

Osuntokun, B. O., Durowoju, J. E., MacFarlane, H. \& Wilson, J. (I968). Br. med. f. iii, 674.

Osuntokun, B. O., Monekosso, G. L. \& Wilson, J. (I969). Br. med. F. i, 547.

Osuntokun, B. O. \& Williams, O. A. (1970). Br. F. exp. Path. (In the Press.)

Saunders, J. P. \& Himwich, W. A. (1950). Am. F. Physiol. 163, 404.

Sorbo, B. (1953). Acta chem. scand. 7, 1129.

Viehoever, A. (1940). Thai Sci. Bull. 2, I.

Vizoso, A. D. \& Young, J. Z. (1948). F. Anat. 82, I Iо.

Williams, O. A. \& Osuntokun, B. O. (1969). Archs Neurol., Chicago 21, 475.

Wilson, J. (1965). Leber's disease. PhD Thesis, University of London.

Wood, J. L. \& Cooley, S. L. (1956). F. biol. Chem. 218, 449. 